\title{
Needs and services at an in-patient psychotherapy unit
}

\author{
JA Joska ${ }^{1}$, AJ Flisher ${ }^{2}$ \\ 'Department of Psychiatry and Mental Health, University of Cape Town, Cape Town, South Africa \\ ${ }^{2}$ Division of Child and Adolescent Psychiatry, Department of Psychiatry and Mental Health, University of Cape Town, \\ Cape Town, South Africa
}

\begin{abstract}
Objective: To describe the impact of services provided, during an admission, on unmet needs and correlates of unmet needs. Method: The study used a modified version of The Camberwell Assessment of Need (CAN) to assess the perceived needs of 100 patients on admission to a psychotherapy unit, Valkenberg Hospital, Cape Town. At discharge, the study documented the extent to which the patients had perceived services and interventions to be useful. Results: The mean number of needs on admission was 8.6. At discharge, help received was highest for psychiatric needs. The services most often regarded as useful were organised group activities and therapies. Regression analysis suggests that a lower level of education and the presence of borderline personality traits contribute significantly to unmet need on discharge. Conclusion: The in-patient program is effective in meeting psychiatric needs, but less useful for addressing psycho-social needs. These needs may exacerbate psychiatric problems and should be managed more actively before, during and after an in-patient stay.
\end{abstract}

Key words: Mental health services; Camberwell assessment of Need; Unmet need

Received: 18-04-2006

Accepted: $13-07-2006$

\section{Introduction}

The assessment of need for mental health services in the community is a first step in developing and planning treatment programs. Most studies in general populations have employed methodologies that yield data on prevalence rates of psychiatric disorders. ${ }^{1-3}$ More recently, instruments designed to measure a broader range of needs of people suffering from mental disorders have been developed, for example the Needs For Care Assessment Schedule (NFCAS) ${ }^{4}$, and the Camberwell Assessment of Need (CAN). ${ }^{5}$ These instruments, although different, assess a range of psycho-social and psychiatric needs, and in the case of the NFCAS, the effect of interventions on needs. As such, not only symptom reduction is sought in this view of comprehensive psychiatric treatment. Another aim is to improve quality of life, the best predictor of which is the number of unmet needs. ${ }^{6}$ There are an increasing number of studies addressing unmet need in psychiatric populations. ${ }^{7}$ However, none have examined the impact of in-patient services on the level of unmet need. The current study had three aims: first, to

\section{Correspondence:}

Dr J Joska

Department of Psychiatry and Mental Health,

Groote Schuur Hospital, Anzio Road, Observatory, 7925, South Africa. email: jjoska@curie.uct.ac.za describe the impact of services provided during an admission on unmet needs; second, to describe which services were perceived to be useful in meeting those needs; third, to examine barriers to meeting need.

\section{Method}

\section{Treatment setting}

Valkenberg Hospital is a specialized psychiatric hospital located in Cape Town. The unit being studied, ward one, admits men and women between the ages of 18 and 60 years. Psychiatric problems treated include depression, anxiety and personality disorders. Individuals are usually referred to the program in crisis either having been in-patients at Valkenberg Hospital, or the Groote Schuur emergency psychiatry unit; or out-patients attending clinics at local community health centres. In most cases, attempts have been made at out-patient management. They are screened telephonically, and the ward program is explained to referrers. Those on the premises i.e. already inpatients at Valkenberg, are screened by interview. Once in the ward, patients are fully interviewed and presented at ward rounds. Patients with active psychosis and suicidal ideation are excluded from the program. In some cases, this only becomes apparent after a time- therefore only patients who had spent two weeks or more on the program were included in the study. During the program, a range of formal and informal interventions 
are offered. A collaborative approach to the admission is encouraged, with the main goals of admission being to ameliorate psychiatric symptoms and promote re-integration into the community. Psycho-social needs are addressed when brought as a focus of clinical attention. Members of the multidisciplinary team include: contact nursing staff, psychiatric registrar and psychology intern (case managers), psychiatrist, psychologist, social worker and occupational therapist.

\section{Sample}

All patients admitted to ward one from 01-01-2003 to 31-01-2004, and who completed the program, were included. Informed consent was taken from all participants. The project was approved by the Health Sciences Faculty Research committee of the University of Cape Town. No conflict of interest was apparent. All patient information was kept confidential and there was no direct feedback between the researchers and the ward team. A patient was deemed to have completed the program if they had spent a minimum period of two weeks in the ward. Program "drop-outs" were those patients who did not comply with program requirements by either breaking ward rules, or who were considered unsuitable for the program. The number of patients admitted to the program varies from two to four per week.

\section{Measures}

The Camberwell Assessment of Need (CAN $)^{5}$ meets the criteria of being a useful instrument for assessing the needs of people with severe mental illness: it is valid and reliable, brief, and easy to administer. ${ }^{8}$ The CAN assesses needs over the preceding month. The original CAN contains 22 domains of need, rated on a 3 point scale: $0=$ no need; $1=$ nolmoderate problem due to intervention; and $2=$ current serious problems. One domain was added ("cigarette smoking") and the domain "psychological distress" was dis-aggregated into a further 3 domains to suit the nature of problems presenting at ward one: "depression", "anxiety", and "post-traumatic stress". An example of a domain is included in Appendix 1. For each domain, where a need is reported, the following sections are completed: current help received from friends or relatives, help needed from local services, adequacy of help received, satisfaction with help received. The section "help required from ward one for this need" was added to the modified CAN. A separate form was created to capture the extent of perceived help at discharge, together with a checklist of formal and informal interventions (Appendix 2).

\section{Procedure}

Interviews were conducted by a trained research assistant. Didactic and clinical training was done, according to a manual provided by the authors of the CAN. The modified CAN was administered on admission. Demographic information was also captured using a report form. At discharge, information regarding the length of stay and diagnosis according the Diagnostic and Statistical Manual, Fourth Edition (DSM IV) was first recorded. Then the degree of help received for each reported need was ascertained using the separately created form. Patients reporting "moderate" or "high" help for the need were asked to comment on the usefulness of a range of interventions compiled by the authors and ward staff $(0=$ not applicable; $1=$ useful; 2 =not useful)

\section{Analysis}

Patient data was recorded onto a database developed using "Microsoft Access 2000" and analysed using "Microsoft Excel 2000". Demographic and service utilization characteristics, the needs of patients on admission, barriers to meeting need and usefulness of services were recorded and are reported as frequencies and percentages. Unpaired t-tests for gender and one-way ANOVAs were used to assess differences between numbers of unmet needs. Separate linear regression models were developed for numbers of unmet needs on discharge, on hypothesized correlates of unmet need.

\section{Results}

All 100 patients who completed the program agreed to participate. Socio-demographic data and service utilization characteristics are shown in Table I. There was a marked preponderance of women $(n=74)$ and unmarried patients $(n=$ 83). Many patients were referred from the psychiatric

\begin{tabular}{|c|c|c|}
\hline \multicolumn{3}{|c|}{ Table I. Socio-demographic characteristrics- $n=100$} \\
\hline & & $n \backslash \%$ \\
\hline Age & $\begin{array}{l}18-25 \\
26-35 \\
36-45 \\
45+\end{array}$ & $\begin{array}{l}16 \\
35 \\
30 \\
19\end{array}$ \\
\hline Gender & $\begin{array}{l}\text { male } \\
\text { female }\end{array}$ & $\begin{array}{l}26 \\
74\end{array}$ \\
\hline Marital status & $\begin{array}{l}\text { Married } \\
\text { Unmarried }\end{array}$ & $\begin{array}{l}12 \\
88\end{array}$ \\
\hline Education & $\begin{array}{l}\text { Std } 6 \\
\text { Std 7-8 } \\
\text { Std } 9-10 \\
\text { Tertiary education }\end{array}$ & $\begin{array}{l}8 \\
19 \\
55 \\
18\end{array}$ \\
\hline Occupation & $\begin{array}{l}\text { Professional } \\
\text { Technical } \\
\text { Artisan } \\
\text { Unemployed }\end{array}$ & $\begin{array}{l}7 \\
13 \\
25 \\
55\end{array}$ \\
\hline Home language & $\begin{array}{l}\text { English } \\
\text { Afrikaans } \\
\text { Xhosa } \\
\text { English and Afrikaans } \\
\text { Other }\end{array}$ & $\begin{array}{l}55 \\
63 \\
4 \\
22 \\
2\end{array}$ \\
\hline Accessibility of services & $\begin{array}{l}\text { Near enough to walk } \\
\text { Needs taxilpublic transport } \\
\text { relies on others for lift } \\
\text { Not easily accessible }\end{array}$ & $\begin{array}{l}89 \\
10 \\
1 \\
0\end{array}$ \\
\hline Duration of problem & $\begin{array}{l}\text { Less than } 1 \text { month } \\
1 \text { to } 3 \text { months } \\
4 \text { to } 6 \text { months } \\
7 \text { to } 12 \text { months } \\
\text { More than } 12 \text { months }\end{array}$ & $\begin{array}{l}5 \\
45 \\
30 \\
13 \\
7\end{array}$ \\
\hline Time since first contact & $\begin{array}{l}\text { Less than } 1 \text { month } \\
1 \text { to } 3 \text { months } \\
4 \text { to } 6 \text { months } \\
7 \text { to } 12 \text { months } \\
\text { More than } 12 \text { months }\end{array}$ & $\begin{array}{l}21 \\
41 \\
21 \\
7 \\
10\end{array}$ \\
\hline Discharge diagnosis & $\begin{array}{l}\text { Depressive disorder } \\
\text { Anxiety disorder } \\
\text { Psychotic disorder } \\
\text { Borderline personality }\end{array}$ & $\begin{array}{l}92 \\
35 \\
3 \\
32\end{array}$ \\
\hline Numbers $(n)=100$ there & flected as percentages & \\
\hline
\end{tabular}


emergency service at Groote Schuur Hospital, Cape Town $(n=30)$. The majority of patients reported easy access to services $(n=89)$, and 75 had experienced the current problem for up to six months. The mean number of total needs was 8.6.

At discharge, the average patient had stayed in ward one for 5.7 weeks (SD 2.4). Most had been diagnosed with a Diagnostic and Statistical Manual 4th edition (DSM-IV) depressive disorder $(n=92)$ and 32 had attracted a diagnosis of borderline personality traits or disorder on axis II (ICD-10 emotionally unstable personality, borderline type). Almost a third $(\mathrm{n}=35)$ were discharged with a diagnosis of an anxiety disorder. Few $(n=3)$ were diagnosed with psychotic disorders.

The numbers of needs on admission are shown in Table II. The highest numbers of needs were reported in psychiatric and inter-personal domains. In these areas, most patients reported a "serious" need. Fewer needs were reported in the areas of "self-care" (n=3) and "physical and sexual abuse" $(n=15)$. The degree of help received for reported needs is also shown in Table II. "Moderate" or "high" help ("met need") was most often received for psychiatric domains: 89.7\% for "depression" and 78.0\% for "anxiety". Interpersonal areas of need were less commonly reported as met.

The usefulness of services according to need is shown in Table III, in which the four most frequent needs domains for each cluster (basic, psycho-social and psychiatric) are shown. Higher levels of usefulness were seen across services for psychiatric needs, while services most consistently rated as useful were support group, life skills and individual therapy.

Patient characteristics for unmet need on discharge were compared using unpaired t-tests or one-way ANOVA's. The results are shown in Table IV. A lower level of education $(p<0.01)$ and the presence of borderline personality $(p=0.03)$ were associated with a significantly higher number of unmet needs. Separate regression models for these characteristics were developed. The finding was significant only for the level of education $(\mathrm{p}<0.01)$. These characteristics explained 17\% of the variance.

\section{Discussion \\ Socio-demographic and diagnostic characteristics}

The general profile of patients admitted to ward one is that of women ( $n=74$ ) between the ages of 25 and $45(n=65)$, who are depressed $(n=92)$. The relative paucity of men could be explained by the fact that men are more likely to be employed and therefore unavailable to attend an in-patient program; that men display a different pattern of help-seeking behaviour during distress; that men are more likely to abuse substances, display anti-social behaviour, or even become psychotic. These are exclusion criteria for the program described in this study. This demographic profile is unusual for most adult in-patient units, and does affect the extent to which these results can be generalised. The marital status of patients is also remarkable: only 12 patients were married at the time of admission. This may suggest that marriage is a protective factor. However, other studies of needs assessment have reported rates of single status of over 60\%., 511,13 Few patients admitted to the program had less than grade 10 level of education ( $n=8)$. The nature of an in-patient therapeutic program, however, may select out more educated and articulate individuals. Just over half of the patients were unemployed- this again should not necessarily be taken to imply that unemployment is associated with severe mental illness, rather, that it commonly co-exists. With regard to discharge diagnosis, a clear preponderance of anxiety and depressive disorders is seen in the discharge diagnosis data-

Table II. Needs on admission and discharge $(N=100)$

\begin{tabular}{|c|c|c|c|c|c|c|c|c|c|}
\hline & \multirow{3}{*}{ Total needs } & \multicolumn{4}{|c|}{ Admission } & \multicolumn{4}{|c|}{ Discharge } \\
\hline & & \multicolumn{2}{|c|}{ Nolmoderate need } & \multicolumn{2}{|c|}{ Serious need } & \multicolumn{2}{|c|}{ Novow help } & \multicolumn{2}{|c|}{ ModerateVhigh help } \\
\hline & & $n$ & $\%$ & $n$ & $\%$ & $n$ & $\%$ & $n$ & $\%$ \\
\hline Accomodation & 17 & 13 & 76.5 & 4 & 23.5 & 13 & 76.5 & 2 & 11.8 \\
\hline Food & 16 & 14 & 87.5 & 2 & 12.5 & 9 & 56.3 & 6 & 37.5 \\
\hline Looking after the home & 17 & 14 & 82.4 & 3 & 17.7 & 9 & 52.9 & 7 & 41.2 \\
\hline Self care & 3 & 3 & 100 & 0 & & 3 & 100 & 0 & 0 \\
\hline Daily activities & 52 & 3 & 5.8 & 49 & 94.2 & 17 & 32.7 & 33 & 63.5 \\
\hline Physical health & 36 & 29 & 80.6 & 7 & 19.4 & 5 & 13.9 & 29 & 80.6 \\
\hline Psychotic symptoms & 34 & 6 & 17.7 & 28 & 82.4 & 15 & 44.1 & 18 & 52.9 \\
\hline Information & 57 & 27 & 47.4 & 30 & 52.6 & 14 & 24.6 & 42 & 73.7 \\
\hline Depression & 97 & 3 & 3.1 & 94 & 96.9 & 9 & 9.3 & 87 & 89.7 \\
\hline Self harm & 79 & 2 & 2.5 & 77 & 97.5 & 26 & 32.9 & 52 & 65.8 \\
\hline Anxiety & 73 & 27 & 36 & 46 & 63 & 15 & 20.6 & 57 & 78 \\
\hline Post traumatic stress & 52 & 8 & 15.4 & 44 & 84.6 & 27 & 51.9 & 24 & 46.2 \\
\hline Safety to others & 42 & 3 & 7.1 & 39 & 92.9 & 21 & 50 & 21 & 50 \\
\hline Physical and sexual abuse & 15 & 4 & 26.7 & 11 & 73.3 & 7 & 46.7 & 8 & 53.3 \\
\hline Alchohol & 11 & 3 & 27.3 & 8 & 72.7 & 5 & 45.5 & 5 & 45.5 \\
\hline Drugs & 4 & 2 & 50 & 2 & 50 & 2 & 50 & 2 & 50 \\
\hline Child care & 22 & 2 & 9.1 & 20 & 90.9 & 12 & 54.5 & 10 & 45.5 \\
\hline Basic education & 0 & 0 & & 0 & & 0 & & 0 & \\
\hline Telephone problem & 0 & 0 & & 0 & & 0 & & 0 & \\
\hline Transport & 10 & 0 & & 10 & 100 & 8 & 80 & 0 & 0 \\
\hline Money & 58 & 37 & 63.8 & 21 & 36.2 & 37 & 63.8 & 20 & 34.5 \\
\hline Disability grant & 14 & 8 & 57.1 & 6 & 42.9 & 2 & 14.3 & 6 & 42.9 \\
\hline Cigarette smoking & 17 & 1 & 5.9 & 16 & 94.1 & 16 & 94.1 & 1 & 5.9 \\
\hline Intimate relationships & 39 & 0 & & 39 & 100 & 19 & 48.7 & 19 & 48.7 \\
\hline Sexual expression & 38 & 1 & 2.6 & 37 & 97.4 & 32 & 84.2 & 5 & 13.2 \\
\hline Company & 52 & 1 & 1.9 & 51 & 98.1 & 22 & 42.3 & 29 & 55.8 \\
\hline
\end{tabular}




\begin{tabular}{|c|c|c|c|c|c|c|c|c|c|c|c|c|c|c|c|c|c|c|c|}
\hline Need & $\begin{array}{c}\text { Total } \\
\text { needs }\end{array}$ & Group & Art & $\begin{array}{l}\text { Life } \\
\text { skills }\end{array}$ & $\begin{array}{c}\text { Group } \\
\text { educate }\end{array}$ & $\begin{array}{c}\text { Plan } \\
\text { leisure }\end{array}$ & $\begin{array}{c}\text { Plan } \\
\text { relaxa- } \\
\text { tion }\end{array}$ & $\begin{array}{c}\text { Ind } \\
\text { theraoy }\end{array}$ & $\begin{array}{c}\text { Informal } \\
\text { work }\end{array}$ & $\begin{array}{c}\text { Family } \backslash \\
\text { couple }\end{array}$ & Empl & $\begin{array}{c}\text { Other } \\
\text { org }\end{array}$ & Intake & $\begin{array}{c}\text { Ward } \\
\text { env }\end{array}$ & Phone & Inf staff & $\begin{array}{l}\text { Ward } \\
\text { routine }\end{array}$ & Visits & $\begin{array}{c}\text { Social } \\
\text { work }\end{array}$ \\
\hline \multicolumn{2}{|l|}{ Basic cluster } & & & & & & & & & & & & & & & & & & \\
\hline Accommodation & 17 & $\begin{array}{c}3 \\
(17.7)\end{array}$ & $\begin{array}{c}3 \\
(17.7)\end{array}$ & $\begin{array}{c}3 \\
(17.7)\end{array}$ & $\begin{array}{c}2 \\
(11.8)\end{array}$ & $\begin{array}{c}2 \\
(11.8)\end{array}$ & $\begin{array}{c}2 \\
(11.8)\end{array}$ & $\begin{array}{c}3 \\
(17.7)\end{array}$ & $\begin{array}{c}3 \\
(17.7)\end{array}$ & (5.9) & $\begin{array}{c}1 \\
(5.9)\end{array}$ & (5.9) & $\begin{array}{c}4 \\
(23.5)\end{array}$ & $\begin{array}{c}4 \\
(23.5)\end{array}$ & 0 & $1(5.9)$ & $\begin{array}{c}2 \\
(11.8)\end{array}$ & $\begin{array}{c}2 \\
(11.8)\end{array}$ & $1(5.9)$ \\
\hline Food & 16 & $\begin{array}{c}3 \\
(18.8)\end{array}$ & $\begin{array}{c}2 \\
(12.5)\end{array}$ & $\begin{array}{c}4 \\
(25.0)\end{array}$ & $\begin{array}{c}2 \\
(12.5)\end{array}$ & $l(6.3)$ & $\begin{array}{c}3 \\
(18.8)\end{array}$ & $\begin{array}{c}3 \\
(18.8)\end{array}$ & $\begin{array}{c}2 \\
(12.5)\end{array}$ & $1(6.3)$ & 0 & 0 & $\begin{array}{c}5 \\
(31.3)\end{array}$ & $\begin{array}{c}3 \\
(18.8)\end{array}$ & 0 & $\begin{array}{c}2 \\
(12.5)\end{array}$ & $\begin{array}{c}5 \\
(31.3)\end{array}$ & 0 & $1(6.3)$ \\
\hline Transport & 10 & $3(30)$ & $3(30)$ & $2(20)$ & $3(30)$ & $2(20)$ & $2(20)$ & $3(30)$ & $2(20)$ & $1(10)$ & 0 & 0 & $3(30)$ & $2(20)$ & 0 & $1(10)$ & $2(20)$ & 0 & $2(20)$ \\
\hline Money & 58 & $\begin{array}{c}7 \\
(12.1)\end{array}$ & $\begin{array}{c}8 \\
(13.8)\end{array}$ & $\begin{array}{c}8 \\
(13.8)\end{array}$ & $5(8.6)$ & $2(3.4)$ & $4(6.9)$ & $\begin{array}{c}17 \\
(29.3)\end{array}$ & $\begin{array}{c}9 \\
(25.5)\end{array}$ & $3(5.2)$ & $\begin{array}{c}1 \\
(1.7)\end{array}$ & $1(1.7)$ & $\begin{array}{c}10 \\
(17.2)\end{array}$ & $\begin{array}{c}8 \\
(13.8)\end{array}$ & $1(1.7)$ & $\begin{array}{c}7 \\
(12.1)\end{array}$ & $4(6.9)$ & $\begin{array}{c}15 \\
(25.9)\end{array}$ & $\begin{array}{c}25 \\
(43.1)\end{array}$ \\
\hline \multicolumn{2}{|c|}{ Psycho-social cluster } & & & & & & & & & & & & & & & & & & \\
\hline \multirow[t]{2}{*}{ Daily activities } & 52 & $\begin{array}{c}22 \\
(42.3)\end{array}$ & $\begin{array}{c}23 \\
(44.2)\end{array}$ & $\begin{array}{c}51 \\
(98.1)\end{array}$ & $\begin{array}{c}21 \\
(40.1)\end{array}$ & $\begin{array}{c}15 \\
(28.9)\end{array}$ & $\begin{array}{c}18 \\
(34.6)\end{array}$ & $\begin{array}{c}29 \\
(55.8)\end{array}$ & $26(50)$ & $\begin{array}{c}9 \\
(17.3)\end{array}$ & $\begin{array}{c}5 \\
(9.6)\end{array}$ & $2(3.9)$ & $\begin{array}{c}27 \\
(51.9)\end{array}$ & $26(50)$ & $\begin{array}{c}11 \\
(21.2)\end{array}$ & $\begin{array}{c}17 \\
(32.7)\end{array}$ & $\begin{array}{c}27 \\
(51.9)\end{array}$ & $\begin{array}{c}9 \\
(17.3)\end{array}$ & $\begin{array}{c}9 \\
(17.3)\end{array}$ \\
\hline & & 6 & 4 & 7 & 5 & 5 & 4 & 9 & 8 & & & & 9 & 4 & & & 5 & & \\
\hline \multirow[t]{2}{*}{ Sexual expressio } & 38 & $(15.8)$ & $(10.5)$ & $(18.4)$ & (13.2) & (13.2) & $(10.5)$ & $(23.7)$ & $(21.1)$ & $2(5.3)$ & 0 & 0 & $(23.7)$ & $(10.5)$ & $2(5.3)$ & $3(7.9)$ & (13.2) & $2(5.3)$ & $1(2.6)$ \\
\hline & & 22 & 18 & 21 & 21 & 19 & & 24 & 21 & & & & 20 & 22 & 12 & 15 & 21 & 8 & 6 \\
\hline Company & 52 & $(42.3)$ & $(34.6)$ & $(40.4)$ & $(40.4)$ & $(36.5)$ & $13(25)$ & $(46.2)$ & $(40.4)$ & $5(9.6)$ & 0 & $2(3.8)$ & $(38.5)$ & $(42.3)$ & $(23.1)$ & $(28.9)$ & $(40.4)$ & $(15.4)$ & (11.5) \\
\hline Intimate & & 15 & 12 & 13 & 11 & 6 & 4 & 17 & 14 & & & & 11 & 14 & 5 & 6 & 8 & 4 & \\
\hline relationships & 39 & $(38.5)$ & $(30.8)$ & $(33.3)$ & (28.2) & (15.4) & $(10.3)$ & $(43.6)$ & $(35.9)$ & $2(5.3)$ & 0 & $1(2.6)$ & $(28.2)$ & $(35.90)$ & $(12.8)$ & (15.4) & $(20.5)$ & $(10.3)$ & $3(7.7)$ \\
\hline \multicolumn{2}{|c|}{ Psychiatric cluster } & & & & & & & & & & & & & & & & & & \\
\hline \multirow{3}{*}{ Information } & & 33 & 25 & 35 & 32 & 15 & 21 & 36 & 33 & 14 & & & 30 & 25 & & 28 & 28 & 14 & 12 \\
\hline & 57 & $(57.9)$ & $(43.9)$ & $(61.4)$ & $(56.1)$ & $(26.3)$ & $(36.8)$ & (63.2) & $(57.9)$ & $(24.6)$ & 0 & $1(1.8)$ & (52.6) & $(43.9)$ & $8(14)$ & $(49.1)$ & $(49.1)$ & $(24.6)$ & (21.1) \\
\hline & & 76 & 67 & 71 & 61 & 45 & 58 & 75 & & 20 & 2 & & 60 & 68 & 34 & 60 & 68 & 38 & 19 \\
\hline \multirow[t]{2}{*}{ Depression } & 97 & $(78.4)$ & $(69.1)$ & (73.2) & (62.9) & $(46.4)$ & (59.8) & (77.3) & $65(67)$ & (20.6) & $(2.1)$ & $2(2.1)$ & (61.9) & (70.1) & $(35.1)$ & $(61.9)$ & $(70.1)$ & $(39.2)$ & (19.6) \\
\hline & & & 36 & 43 & 33 & 23 & 32 & 47 & 42 & 10 & 1 & & & 47 & 21 & & 35 & 18 & 13 \\
\hline \multirow[t]{2}{*}{ Self harm } & 79 & $45(56)$ & $(45.6)$ & $(54.4)$ & $(41.8)$ & $(29.10)$ & $(40.5)$ & (59.5) & (53.2) & (12.7) & $(1.3)$ & 0 & $45(56)$ & (59.5) & (26.6) & $34(43)$ & $(44.3)$ & $(22.8)$ & (16.5) \\
\hline & & 35 & 32 & 40 & 35 & 23 & 36 & 45 & 34 & 11 & 1 & & 36 & 36 & 15 & 36 & 34 & 15 & 9 \\
\hline Anxiety & 73 & $(47.9)$ & $(43.8)$ & (54.8) & $(47.9)$ & $(31.5)$ & $(49.3)$ & (61.6) & $(46.6)$ & $(15.1)$ & $(1.4)$ & 0 & $(49.3)$ & (49.3) & $(20.6)$ & $(49.3)$ & $(46.6)$ & (20.6) & (12.3) \\
\hline
\end{tabular}

\section{Table IV. Comparison of patient characteristics for unmet need on discharge (t-test or ANOVA)}

\begin{tabular}{|c|c|c|c|c|c|c|c|}
\hline Variable & Category & $n$ & mean & $S D$ & $t \vee F$ & $d f$ & $P$ \\
\hline Age & $\begin{array}{l}18-24 \\
26-34 \\
35-44 \\
45+\end{array}$ & $\begin{array}{l}15 \\
36 \\
26 \\
23\end{array}$ & $\begin{array}{l}4.29 \\
3.37 \\
3.61 \\
3.09\end{array}$ & $\begin{array}{c}3.79 \\
2.18 \\
3 \\
2.5\end{array}$ & 0.59 & 3 & 0.62 \\
\hline Gender & $\begin{array}{l}\text { male } \\
\text { female }\end{array}$ & $\begin{array}{l}74 \\
36\end{array}$ & $\begin{array}{l}3.58 \\
3.27\end{array}$ & $\begin{array}{l}2.93 \\
2.12\end{array}$ & 0.39 & 58 & 0.35 \\
\hline Marital status & $\begin{array}{l}\text { Unmarried } \\
\text { Married }\end{array}$ & $\begin{array}{l}54 \\
46\end{array}$ & $\begin{array}{l}6.33 \\
6.45\end{array}$ & $\begin{array}{l}2.71 \\
2.99\end{array}$ & 0.09 & 13 & 0.46 \\
\hline Education & $\begin{array}{l}\text { Std } 6 \\
\text { Std 7-8 } \\
\text { Std 9-10 } \\
\text { Tertiary education }\end{array}$ & $\begin{array}{l}8 \\
19 \\
55 \\
18\end{array}$ & $\begin{array}{l}6.5 \\
3.89 \\
3.15 \\
2.79\end{array}$ & $\begin{array}{c}3.7 \\
2.26 \\
2.63 \\
2.3\end{array}$ & 4.4 & 3 & $<0.01$ \\
\hline Number of admissions & $\begin{array}{l}\text { None } \\
1 \text { to } 2 \\
3 \text { to } 5 \\
6 \text { or more }\end{array}$ & $\begin{array}{c}27 \\
44 \\
21 \\
8\end{array}$ & $\begin{array}{c}3.29 \\
3.16 \\
4.8 \\
2.86\end{array}$ & $\begin{array}{l}2.66 \\
2.55 \\
3.29 \\
1.81\end{array}$ & 1.98 & 3 & 0.12 \\
\hline Duration of admission & $\begin{array}{l}\text { 2-4 weeks } \\
5-6 \text { weeks } \\
\text { 7-8 weeks } \\
9 \text { or more weeks }\end{array}$ & $\begin{array}{l}34 \\
30 \\
26 \\
10\end{array}$ & $\begin{array}{c}3.33 \\
3.4 \\
4.04 \\
3.1\end{array}$ & $\begin{array}{l}3.19 \\
2.4 \\
2.77 \\
1.91\end{array}$ & 0.43 & 3 & 0.73 \\
\hline Axis I depressive disorder only & $\begin{array}{l}\text { Yes } \\
\text { No }\end{array}$ & $\begin{array}{l}31 \\
69\end{array}$ & $\begin{array}{l}3.69 \\
3.41\end{array}$ & $\begin{array}{c}2.56 \\
2.8\end{array}$ & 0.48 & 65 & 0.31 \\
\hline Axis II borderline personality & $\begin{array}{l}\text { Yes } \\
\text { No }\end{array}$ & $\begin{array}{l}32 \\
68\end{array}$ & $\begin{array}{l}4.3 \\
3.1\end{array}$ & $\begin{array}{c}3.22 \\
2.4\end{array}$ & 1.9 & 50 & 0.03 \\
\hline
\end{tabular}


in keeping with the nature of service provided at ward one. The high numbers of patients with DSM-IV depressive disorder ( $\mathrm{n}=92)$ and axis II borderline personality traits or disorder ( $n=32$ ) may simply represent the nature of individuals presenting to this kind of program, or that the borderline personality has been over-diagnosed. The latter may be the result of affective disturbance causing poor interpersonal relations in a group of highly distressed individuals.

\section{Service utilization characteristics}

The vast majority of patients ( $n=89$ ) found local services to be easily accessible and were able to walk there. However, proximity of services should not be equated with availability of interventions. Most patients had made a recent service contact for their problem. This again suggests that services are accessible, and also that for these patients, referral to the in-patient unit was possible within six months. Other studies reviewing needs in mentally ill samples have found longer periods before service contact, although most of these were samples of patients with schizophrenia. ${ }^{14,9}$

\section{Needs on admission}

The average number of total needs per patient of 8.6 reported in this sample is consistent with some studies: 7.68.6 in a severely ill British population ${ }^{5}$, and a mean number of needs of 7.5 in another British sample. ${ }^{15}$ Other authors have reported lower numbers of needs, ranging from $5.3^{8}$ to 3.3. ${ }^{16}$ These discrepancies may reflect socio-economic differences, or methodological issues, although all the abovementioned studies used the CAN. With respect to specific domains of need, higher numbers of needs were seen in the cluster of psychiatric needs: "depression" (n=92), "anxiety" ( $\mathrm{n}=73$ ) and "post-traumatic stress" (n=52). Inter-personal needs domains were also commonly reported, but to a lesser degree:

"intimate relationships" (n=39), "sexual expression" (n=38) and "company" ( $\mathrm{n}=52)$. This pattern suggests a link between relationships and the development of depressive and anxiety disorders. Lefebre et a ${ }^{12}$ reported that a risk of higher number of unmet needs was associated with poor intimate relationships and difficulties in the primary social network. Needs for services in the cluster of basic needs were reported least commonly. The low reporting of needs in the domains of "alcohol" (1 l) and "drugs" (4) is surprising, as it is the authors' impression that these problems are more widespread. It must be borne in mind that the CAN here was administered to patients, and not staff i.e. staff perceptions/impressions of need are not necessarily congruent with patient reporting of needs.

\section{Unmet need at discharge}

At discharge, it appeared as though needs were more likely to be met in physical and psychiatric domains- this finding is not unexpected, given that ward one aims to provide a setting for stabilizing acute psychiatric problems, while addressing aggravating psycho-social issues as best as possible during the admission. Fewer patients reported being helped in certain basic areas. The addressing of basic needs is a complex one. While few would argue that community-based services should be able to address these needs, and by so doing prevent some admissions, there is a severe paucity of resources. If social needs are highlighted by an admission, perhaps a collaborative approach is called for- these could then be addressed in an ongoing manner. The use of admission in order to obtain disability grants is a case in point. In psycho-social areas, such as sexual problems, patients not receiving help may have felt embarrassed by the sensitive nature of this domain. The relative frequency of this problem $(n=38)$ and the low degree of help received $(n=32)$ could prompt the ward team to take special measures to deal with these issues. In this way, doing a CAN assessment on admission highlights a need that may have otherwise been unreported and untreated.

A number of needs domains were only partly addressed. For example, patients in ward one frequently present with post-traumatic stress (52,0\%), while only $46.2 \%$ of these were adequately helped. It is, however, rare that these individuals present without other co-morbid problems. In many cases, post-traumatic stress is complex and embedded within borderline personality. Furthermore, it is not always possible to guarantee patient's safety on weekend leave and discharge- in some communities, where perpetrators are released on bail and heighten patients' perception of threat. This merely perpetuates the clinical problem of posttraumatic stress.

\section{Usefulness of services according to need}

The numbers of patients finding services useful can be viewed in two ways: firstly, from the needs point of view, and secondly, from the services point of view. The usefulness of services is clustered around the psychiatric and medical needs, suggesting that these needs are easier to meet. This can be seen as an important form of positive feedback for the program, in that they are addressing the commonly reported psychiatric needs in effective ways. Conversely, patients do not find the available service useful in meeting other needs areas, and ways need to be found to address this deficiency. From the service point of view, interventions that address skills or function domains are more difficult to structure, and require more resources. Services that offer some form of support or counseling appear to be most useful: support groups, individual therapy, projective art, life skills and informal patient interactions, were most commonly cited as helpful. These services may afford patients the opportunity for expression and communication, which reflect their deficiencies in primary social relationships and networks.

\section{Correlates of unmet need}

The numbers of needs of patients on discharge with different levels of education was significantly different $(p<0.01)$. Lower levels of education may contribute to higher numbers of unmet needs by virtue of patients having fewer coping skills, poor problem-solving abilities and a diminished capacity to engage in social structures. In addition, patients with borderline personality had a significantly higher number of unmet needs. This is not altogether surprising, as these patients frequently present in crisis, which may generate large numbers of unmet needs. Co-morbidity in the borderline patient is correlated with a higher number and frequency of suicide attempts. ${ }^{17}$

This study had a number of important limitations. For example, the sample size was small and the study was 
confined to one ward at one hospital. However, we believe that the study has contributed through being the first study in which an assessment has been made of the extent to which unmet needs are addressed during a hospital admission.

\section{Conclusion}

Where psycho-social needs perpetuate psychiatric problems, a more formal approach to the assessment of need may be useful. Whilst clinical needs are more readily addressed by existing programs, basic psycho-social and interpersonal needs could be addressed collaboratively both in the community and by specialist services. Further research examining the meeting of needs of in-patient groups versus out-patient groups may further our understanding of where services could be improved and resources directed.

\section{Acknowledgements}

This study was funded by the Medical Research Council of South Africa. The authors thank Ms Jocelyn Warden for data collection.

\section{References}

1. Bijl RV, Ravelli, A: Psychiatric Morbidity, Service Use, and Need for Care in the General Population: Results of the Netherlands Mental Health Survey and Incidence Study. American Journal of Public Health 2000: 90: 602-607.

2. Boyle M, Offord D, Campbell D, Catlin G, Goering P, Lin E, et al. Mental Health Supplement to the Ontario Health Survey: Methodology. Canadian Journal of Psychiatry 1996; 41: 549-558.

3. The World Mental Health Survey Consortium: Prevalence, Severity, and Unmet Need for Treatment of Mental Disorders in the World Health Organisation World Mental Health Surveys. Journal of the American Medical Association 2004; 291: 2581-2590.

4. Brewin CR, Wing JK, Mangen SP, Brugha TS, MacCarthy B. Principles and practice of measuring needs in the long-term mentally ill: the MRC Needs for Care Assessment. Psychological Medicine 1987; 17: 971-981.

5. Phelan M, Slade M, Thornicroft G, Dunn G, Holloway F, Wykes T, et al. The Camberwell Assessment of Need: the validity and reliability of an instrument to assess the need of people with severe mental illness. British Journal of Psychiatry 1995; 167: 589-595.
6. Slade M. Routine outcome assessment in mental health services. Psychological Medicine 2002; 32: 1339-1343.

7. Joska J. Flisher AJ. The assessment of need for mental health services. Social Psychiatry and Psychiatric Epidemiology 2005; 40: 529-539.

8. Hansson L, Bjorkman T, Svensson, B. The assessment of needs in psychiatric patients- Interrater reliability of the Swedish version of the Camberwell Assessment of Needs instrument and results from a cross-sectional study. Acta Psychiatrica Scandanavica 1995; 92: 285293.

9. Leese M, Johnson S, Slade M, Parkman S, Kelly F, Phelan M, et al. User perspective on needs and satisfaction with mental health services. British Journal of Psychiatry 1998; 173: 409-415.

10. Parkman $S$, Davies $S$, Leese $M$, et al. Ethnic differences in satisfaction with mental services among representative people with psychosis in South London: PRISM Study 4. British Journal of Psychiatry 1997; 171: 260-264.

11. Meadows G, Fossey E, Harvey C, Burgess P. The assessment of need. In: Andrews, G. and Henderson, S., eds, Unmet Need in Psychiatry, Problems, Resources, Responses. Cambridge University Press, Cambridge 2000:390-398.

12. Lefebre J, Cyr M, Lesage A, Fournier L, Toupin J. Unmet needs in the community: can existing services meet them ? Acta Psychiatrica Scandanavica 2000; 102: 65-70

13. McCrone P, Leese M, Thornicroft G, Schene A, Knudsen HC, VasqezBarquero JL, et al. and the Epsilon Study Group. Reliability of the Camberwell Assessment of Need-European Version. British Journal of Psychiatry 2000; 177: Supplement 39, s34-40.

14. Bengtsson-Tops L, Hansson L. Clinical and social needs of schizophrenic outpatients living in the community: the relationship between needs and subjective quality of life. Social Psychiatry and Psychiatric Epidemiology 1999; 34: 513-518.

15. Slade $M$, Leese $M$, Taylor $R$, Thornicroft $G$. The association between needs and quality of life in epidemiologically representative sample of patients with psychosis. Acta Psychiatrica Scandanavica 1999; 100: 149-157.

16. Lasalvia A, Ruggeri M, Mazzi MA, Dall'Agnola RB. The perception of needs for care in staff and patients in community-based mental health services. The South-Verona Outcome Project 3. Acta Psychiatrica Scandanavica 2000; 102: 366-375.

17. Bank P, Silk K. Axis I and axis II interactions. Current Opinion in Psychiatry 2001; 14: 137-142 
Appendix 1. Camberwell Assessment of Need-modified: domain "Accommodation"

\section{ACCOMODATION}

DOES THE PERSON HAVE A PROBLEM WITH ACCOMODATION?

Do you have a place in which to live?

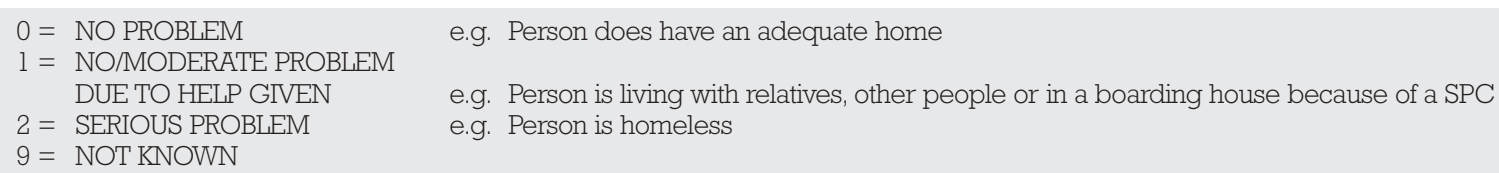

e.g. Person does have an adequate home

e.g. Person is living with relatives, other people or in a boarding house because of a SPC

e.g. Person is homeless

IF RATED 0 OR 9 GO TO THE NEXT QUESTION

HOW MUCH HELP HAS THE PERSON RECEIVED FROIM FRIENDS OR RELATIVES WITH ACCOIMODATION?

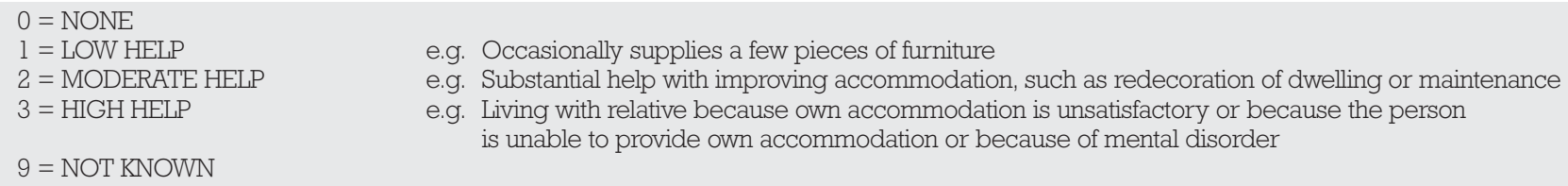

e.g. Living with relative because own accommodation is unsatisfactory or because the person is unable to provide own accommodation or because of mental disorder

\section{HOW MUCH HELP HAS THE PERSON RECEIVED FROIM LOCAL SERVICES WITH THEIR ACCOMODATION?}

\section{HOW IMUCH HELP HAS THE PERSON NEEDED FROIM LOCAL SERVICES WITH THEIR ACCOIMODATION?}

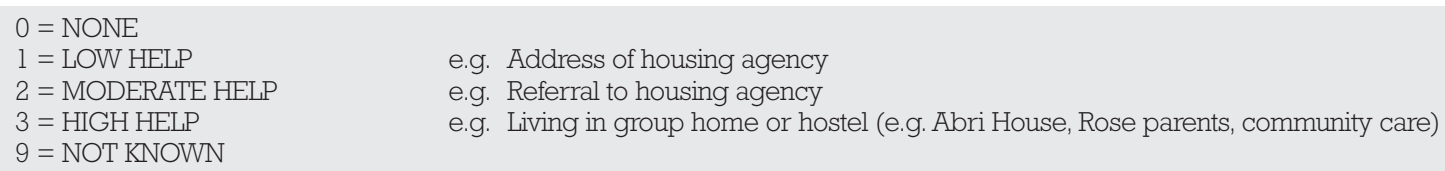

HAS THE PERSON RECEIVED THE RIGHT TYPE OF HELP WITH THEIR ACCOIMODATION?

(0 = NO; 1 = YES; 9 = NOT KNOWN)

OVERALL, IS THE PERSON SATISFIED WITH THE AMOUNT OF HELP THEY HAVE RECEIVED WITH THEIR ACCOIMODATION? (0 = NOT SATISFIED; 1 = SATISFIED; 9 = NOT KNOWN)

HOW MUCH HELP DOES THE PERSON NEED FROIM WARD ONE WITH ACCOIMIMDATION? (0 = NONE; 1 = LOW HELP; 2 = MODERATE HELP; 3 = HIGH HELP; 9 = NOT KNOWN) 


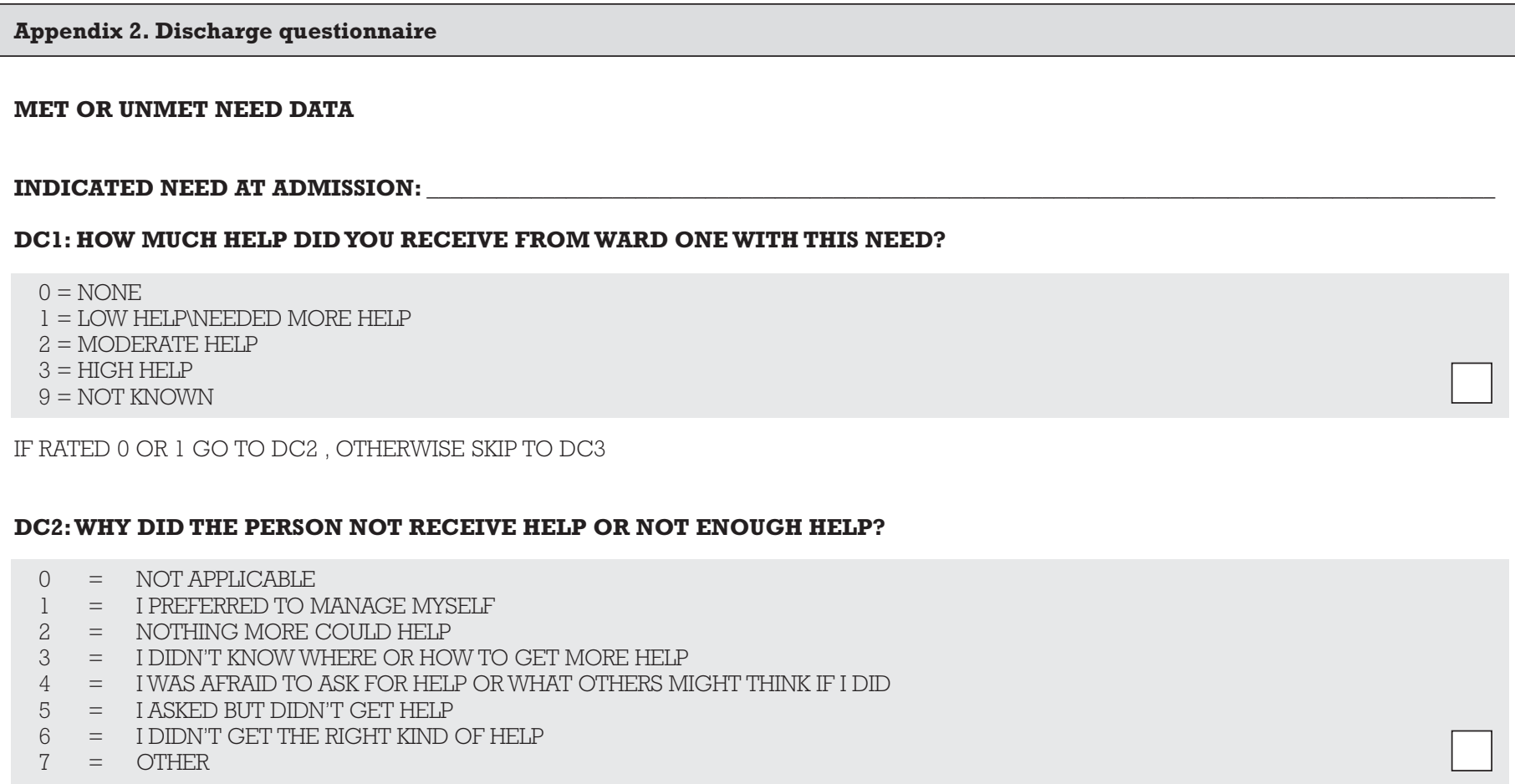

DC3: HOW WAS THIS NEED MET?

(INDICATE THE ONE OR MORE ITEMS THAT SIGNIFICANTLY HELPED THE PERSON WITH THAT PARTICULAR NEED)

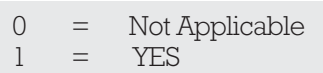

$1=$ YES

$2=\mathrm{NO}$

SUPPORT GROUPS i.e. time in group therapy

PROJECTIVE ART i.e. staff led art program

LIFE SKILLS i.e. anger management or problem-solving

GROUP EDUCATION i.e. learning about mental illness in groups

PLANNED LEISURE ACTIVITIES i.e. horse-riding or organized activities

PLANNED RELAXATION i.e. stretching or breathing excercises

INDIVIDUAL COUNSELLINGITHERAPY i.e.. talking with therapist alone

INFORMAL INTERACTIONS WITH OTHER PATIENTS i.e..smoker's room

FAMILY OR COUPLE SESSIONS i.e.. talking through issues with therapist

EMPLOYMENT ASSISTANCE i.e.liaison or help finding employment

OTHER ORGANISATION i.e. going to AA meetings or rape crisis

INTAKE INTERVIEW i.e.. identifying problems and meeting staff

WARD ENVIRONMENT i.e.. being away from home or work

TELEPHONE IN WARD i.e.. communicating with friends and family

INFORMAL INTERACTIONS WITH STAFF i.e.. talking to nurses

WARD ROUTINE i.e having weekend feedback, goals and tasks, ward duties and Keeping regular hours

VISITING TIME i.e. visits by friends and family to ward

SOCIAL WORK i.e. help with finding accommodation or obtaining a disability Grant

OVERALL, IS THE PERSON SATISFIED WITH THE AMOUNT OF HELP THEY HAVE RECEIVED FOR

THIS PARTICULAR NEED?

( 0 = NOT SATISFIED; 1 = SATISFIED $)$ 